\title{
IMPROVED METHODS FOR THE PREPARATION OF FISH SAUSAGE FROM THE UNWASHED MIXED MINCES OF LOW-COST MARINE FISH
}

\author{
A. AKM Nowsad, M. S. Hoque, M. I. Hossain and M. H. Shikha \\ Department of Fisheries Technology, Bangladesh Agricultural University \\ Mymensingh-2202, Bangladesh
}

\begin{abstract}
Fish sausage was prepared from the unwashed minces of 5 low-cost marine fishes (LMF) viz., red jewfish (Johnius orgentatus), sea cat fish (Tachysurus thalassinus), jwelled shad (Ilisha filigera) horse mackeral (Megalaspis cordyla) and skipjack tuna (Sarda orientialis) of the Bay of Bengal. Six different blend compositions from 5 individual minces of LMF were prepared by blending 15 to $30 \%$ of the individuals minces. Sausage was prepared from such mince blends by improving the textural strength of the products through different cooking process, ingredients and spices. Textural quality was determined in terms of gel strength, cook loss, sensory softness/firmness (S/F) and chewiness/rubburiness $(\mathrm{C} / \mathrm{R})$. Proximate composition and gel forming ability of individual mince blend varied with compositional differences of individuals species. Among the six blends tested, blend $\mathrm{C}$ showed highest gel strength which constituted with higher proportion of mince from red jewfish, sea cat fish and horse mackerel. In mince blend C, composition of red jewfish, sea cat fish, horse mackerel, jeweled shad and skipjack tuna were $30 \%, 20 \%, 20 \%, 15 \%$ and $15 \%$, respectively. Unwashed and washed individual minces and the mince blend $\mathrm{C}$ were incubated at different temperatures from $35^{\circ}$ to $55^{\circ} \mathrm{C}$ and then cooked at $90^{\circ}$ or $100^{\circ} \mathrm{C}$. Among different heating regimes, unwashed mince blend $\mathrm{C}$ showed the highest gel strength at $50^{\circ} \mathrm{C}$ for $1 \mathrm{hr}$ incubation. Further cooking of the incubated gel at $100^{\circ} \mathrm{C}$ optimally increased the gelling ability. Among the four cooking methods tested, (boiling, two-step heating, broiling and autoclaving) autoclave cooking at $115^{\circ} \mathrm{C}$ obtained best textured sausage with significantly increased breaking force, folding test score and chewiness/rubberiness values and decreased cook loss values. Sausages prepared at $115^{\circ}$ and $120^{\circ} \mathrm{C}$, however, showed almost identical textural quality. Texture and flavor of sausage was affected by washing of the mince but the sensory qualities were unaffected.
\end{abstract}

Key Words : Low-cost marine fish, Unwashed mince, Mince blend, Fish sausage, High temperature-high pressure gel

\section{INTRODUCTION}

Bangladesh is diverse in marine fish species but lacking of mono-species fishery in large quantity to be used as raw material for a particular product (Nowsad et al., 2004). Individual catch size of small meso-pelagic/pelagic species like small sea catfish, jewfish, skipjack tuna, jwelled shad, horse mackerel etc. is too small to run a sustainable 
product line, but their mixed lot can make a significant volume to produce any value added product. Blending of different fish minces often produce low quality products because of interactions of proteins, lipids and enzymes of different origin and nature. Therefore, a mechanism should be developed first to improve the gel quality of such blended mince before going to manufacturing any value added product from it.

Fast foods are being popularized and the business is expanding in the country very fast (Nowsad, 2006). Fish sausage is a major item of new generation fast food, because of overwhelming young generation craze for its superb taste, fabricated texture, brilliant colour and high nutritional quality. As a convenient food, it is becoming increasingly popular to the working people too. Fish sausage prepared from the mixed mince of underutilized fishes would be able to serve a good taste and nutrition to such people in cheaper price. Good quality fish sausages would have good sensory taste that can be obtained by mixing with various spices ingredients.

Value-added products are generally prepared from the washed mince or surimi to achieve high elasticity in the product. Washing of mince eliminates gel interfering elements like sarcoplasmic proteins, lipids, bloods, enzymes and minerals (Lee, 1884; Rappond et al., 1995; Roussel and Chfhtel, 1988). During this washing process more than $50 \%$ of the mince are lost which are valuable proteins and lipids, very useful for the consumer (Nowsad, 2006). Removal of such valuable nutrients for the improvement of gel elasticity is considered to be a wastage of resource in a poor country like Bangladesh. Therefore, in this study, efforts will be made to utilize unwashed mince in fish sausage production, in stead of washed mince or surimi.

Considering the above facts, it is felt necessary to formulate and develop fish sausage from the unwashed mixed minces of low-cost marine fishes by using local ingredients and spices. This is the first investigation elsewhere on the manufacture of fish sausage from the unwashed mixed minces of LMF.

\section{MATERIALS AND METHODS}

\section{Species of fish}

Five low-cost underutilized marine fish species (LMF) like small red jewfish (Johnius orgentatus), small sea catfish (Tachysurus thalassinus), horse mackerel (Megalaspis cordyla), jeweled shad (Ilisha filigera) and skipjack tuna (Sarda orientialis) were selected for this study. These marine fish species have limited use in commercial production, low price on the fresh fish market and are abundantly available in Bangladesh marine water.

\section{Collection of raw materials}

Iced fishes were purchased from the Kawran Bazar wholesale fish market in Dhaka. Immediately after purchase the fish were re-iced with new crushed ice in an insulated ice box. The average weight of red jewfish (Johnius orgentatus), sea catfish (Tachysurus thalassinus), horse mackeral (Megalaspis cordyla), jwelled shad (Ilisha filigera) and skipjack tuna (Sarda orientialis) were $0.34 \pm 0.04,2.60 \pm 59,0.44 \pm 0.04,1.11 \pm 0.25$ and $1.80 \pm 0.52 \mathrm{~kg}$ 
and average length were $12.05 \pm 1.5,45.0 \pm 3.74,12.40 \pm 2.4,20.3 \pm 4.22$ and $26.52 \pm 2.1 \mathrm{~cm}$, respectively (Fig. 1). After brought to the laboratory the raw materials were frozen stored in a freezer $\left(-20^{\circ} \mathrm{C}\right)$.

\section{Preparation of mince blend}

The fishes were washed, deheaded and eviscerated. The skinned fishes were filleted and deboned manually in iced condition. Then mince were prepared by a mechanical mincer (National Meat Grinder, MK-G3NS, Matsushita Electric Industrial Co. Ltd., Osaka, Japan.) through a $1 \mathrm{~mm}$ orifice diameter so that all bones and connective tissues were removed from the muscles. Six mince blends (A, B, C, D, E and F) were prepared with blending composition given in Table 1.

Table 1. Composition of mince blends

\begin{tabular}{l|c|c|c|c|c|c}
\hline \multirow{1}{*}{ Species } & \multicolumn{7}{c}{ Composition (\%) mince } \\
\cline { 2 - 7 } & $\mathrm{A}$ & $\mathrm{B}$ & $\mathrm{C}$ & $\mathrm{D}$ & $\mathrm{E}$ & $\mathrm{F}$ \\
\hline Red jewfish & 20 & 20 & 30 & 15 & 15 & 20 \\
Sea catfish & 20 & 30 & 20 & 15 & 20 & 15 \\
Horse mackerel & 20 & 20 & 20 & 20 & 15 & 15 \\
Jwelled shad & 20 & 15 & 15 & 20 & 20 & 30 \\
Skipjack tuna & 20 & 15 & 15 & 30 & 30 & 20 \\
\hline Total & 100 & 100 & 100 & 100 & 100 & 100 \\
\hline
\end{tabular}

All the procedure from the mincing of fish to filling of paste in the casing were done at around 5 to $8^{\circ} \mathrm{C}$. This was ensured by keeping sufficient ice around fish, flesh and mince. Ice was made available through an ice maker (Lab Tech Ice Macker, Series L cm-200m, R4044A, UK). A portion of the mince blend was washed with chilled $0.1 \% \mathrm{NaCl}$ to see the washing effect of the mince on the quality of fish sausage.

\section{Selection of mince blend}

Six mince blends were separately ground with $2.5 \% \mathrm{NaCl}$, stuffed into sausage casings, cooked at $90^{\circ} \mathrm{C}$ for $30 \mathrm{~min}$ and gel thus formed were evaluated for the gelling performance of the blends. Blend number $C$ where minces from red jewfish, sea catfish, horse mackerel, jeweled shad and skipjack tuna were blended at a rate of 30, 20, 20, 15 and $15 \%$ gave the best quality gel. In the following experiments for the preparation of sausage, blend number $\mathrm{C}$ was used.

\section{Preparation of fish sausage}

Fresh unwashed mince blend $C$ was used for the preparation of fish sausage. Various ingredients were incorporated into mixed mince to improve the textural quality fish sausage. For these purpose various local spice like onion, garlic, ginger, cinnamon, clove, red pepper, black pepper etc. were purchased from the local market. The spices were dried in hot air oven at $60^{\circ} \mathrm{C}$ for $24 \mathrm{hr}$. The dried spice were ground with a mechanical 
grinder to make powder and sieved by a fine mesh metallic sieve. Mince blend $\mathrm{C}$ was ground with $2.5 \% \mathrm{NaCl}, 1.6 \%$ Sugar, $0.1 \%$ monosodium glutamate (MSG), $1.5 \%$ various spices, $2 \%$ vegetable oil, $10 \%$ mashed potato and starch (pure extract). Grinding was done for a total period of $20 \mathrm{~min}$. The ground paste was stuffed into a sausages casing (Krehalon casing, $2.8 \mathrm{~cm}$ diameter, $8 \mathrm{~cm}$ long with Kureha Chemical Co., Tokyo, Japan) by a manual stuffer, both ends of the casing was sealed with cotton twine after removing any air baubles from the casing. Performance of fish sausage was determined under different cooking process like, two-step heating (incubation at $35^{\circ}$ to $55^{\circ} \mathrm{C}$ for $60 \mathrm{~min}$. and then cooking at $90-100^{\circ} \mathrm{C}$ for $30 \mathrm{~min}$ ); boiling (20-60 min); broiling/steaming (20-40 min); and autoclave cooking $\left(110-125^{\circ} \mathrm{C}\right.$ at 15 Ibs.inch- ${ }^{2}$ for 10 to $\left.20 \mathrm{~min}\right)$ Fig. 2.

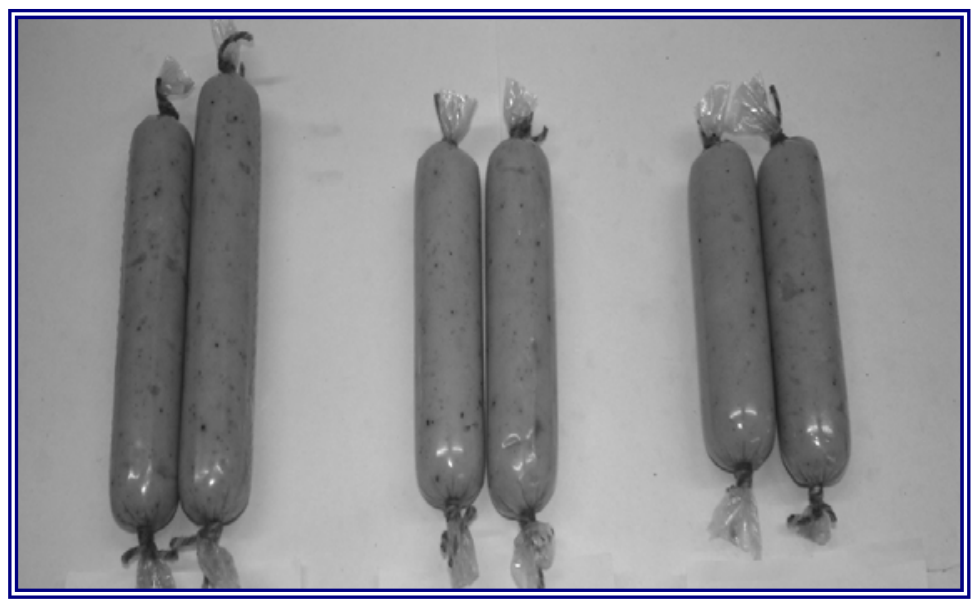

Fig. 1. A nice looking fish sausage prepared from mince blend C

\section{Quality of the fish sausage}

\section{Instrumental gel strength}

Fish sausage prepared from the mince blend C of LMF was subjected to instrumental gel quality analysis through the puncture test. Puncture test was carried out by a food rheometer (Nowsad et al., 2000a) on the test sample $(2.0 \mathrm{~cm}$ height) at a table speed of 10 $\mathrm{cm}$ per min. with a spherical plunger $(6 \mathrm{~cm}$ diameter). The breaking strength (BS) in $\mathrm{g}$ and the breaking deformation (BD) in $\mathrm{cm}$ were calculated from the chart of a potentiometric recorder. Gel strength (GS) denotes the product of breaking strength and breaking deformation, expressed as $\mathrm{g} \times \mathrm{cm}$.

\section{Sensory test}

A panel of nine-person of students, teachers and staff of the Department of Fisheries Technology provided the sensory assessments of the products (Nowsad et al., 2000a). Prior to testing, panelists were familiarized with the properties of meat gel and the instructions relating to the scoring of the sample. Pretests were done with selected samples to familiarize the panelists with the measurement procedure. Three discs of gel $(0.5 \mathrm{~cm}$ thick) were supplied to each panelist to recognize every attribute. 
Softness/firmness (S/F) was defined as the amount of force required to bite through the sample with incisors and chewness/rubbriness $(C / R)$ was defined as the amount of effort the panelist had to exert in chewing to prepare the sample for swallowing. The quality was evaluated by the numerical scores up to 10 , where for $\mathrm{S} / \mathrm{F}, 1$ = very soft; $10=$ extremely firm and for C/R, 1 = not chewy/rubbery; 10 = extremely chewy/rubbery (Szczesniak et al., 1963).

\section{Folding Test}

A folding test was carried out by folding a $2 \mathrm{~mm}$ thick sample disc into halves and quarters as per the method developed by Nowsad et al. (2000a). The scale was $\mathrm{A}^{++}=$no crack when folded into quarters, $\mathrm{A}^{+}=$no crack when folded into half but crack when folded in quarter, $\mathrm{A}=$ crack when folded into half, $\mathrm{B}^{+}=$broke and split into halves.

\section{Biochemical test}

For $\mathrm{pH}$, the mince blend and fish sausage homogenate were prepared by blending $10 \mathrm{~g}$ of mince or sausage with $40 \mathrm{ml}$ of chilled water each. The $\mathrm{pH}$ values were measured by using a laboratory $\mathrm{pH}$ meter. Average of the readings from three different measurements for each of the samples was taken. Three samples from each of unwashed and washed minces and cooked fish sausages were analyzed for proximate composition such as crude protein (Kjeldahl), crude lipid, moisture and ash content. The proximate composition in triplicate from each of unwashed and washed minces and cooked sausage samples were analyzed on wet weight basis according to AOAC (1990).

\section{RESULTS AND DISCUSSION}

Although data not shown here, but the analysis of proximate composition showed that the fishes had moderate moisture content. Protein content showed a moderate level in sea catfish, red jewfish and jeweled shad, while jeweled shad, horse mackerel and skipjack tuna showed higher lipid content. There was an inverse relationship found between the protein and lipid contents. It might be due to size variation and seasonal differences of the fish taken. Various authors (Bertak and Karahadian, 1995; Reppond et al., 1995; Shimizu et al., 1981) found that lipid content was absolutely depended on season and bigger size fish contained more lipid. Compositions of mince blends as analyzed (Table 2) were significantly influenced by such individual proximate composition of fish shown elsewhere (Nowsad et al., 2007). Table 2 shows the proximate composition and $\mathrm{pH}$ of unwashed and washed mince blend No. C and sausage prepared from it. When sausage was prepared from such unwashed blend, both protein and lipid content were reduced, while ash content was increased than washed mince blend. The results supported the findings of Nowsad et al. (2000a) who observed a significant loss of lipid in cooked sausage. The $\mathrm{pH}$ was always above than 6.0 in both minces and cooked products. Washing of the mince blend improved the $\mathrm{pH}$ condition but reduced the protein content due to high moisture reduction.

To draw the maximum possible benefit from a resource for any product, total or whole utilization of the resource is obviously important. Various studies showed that about 40- 
$50 \%$ of the unwashed mince could be obtained from the whole fish, depending on the species, after reducing the loss due to dressing, heading and mincing (Table 3). The suitability of frames, bones and heads in the production of fishmeal was tested. In commercial practice head could be sold in the market for human consumption. The frame might again provide a 3-5\% more mince to the total mince. The remaining bone of the frame could be used for animal feed production. Washing process eliminates gelinterfering substances those interfere with the polymerization of protein, such as sarcoplasmic proteins, enzymes, lipid, blood, minerals and other organic and nitrogenous compounds from the mince, thus improves the textural quality by concentrating gel strengthening myofibrillar protein (Lee, 1984). Similar results have reported by many authors working with other fish species (Nowsad et al., 2000b; Babbitt et al., 1985; Webb et al., 1985). This study showed that percent solid content decreased in washed mince than the unwashed mince, causing a substantial loss of total protein in the mince. Though the total protein and percent solid were decreased, the total mince weight was increased in washed mince due to absorbance of water. Using of unwashed mince could be able to minimize such huge unwanted loss of valuable nutrients. This would also substantially reduce the cost of production by increasing the weight of final products, where materials loss would be very low. Obviously, this utilization of unwashed mince in heat processed products will enhance the noble initiative of 'total utilization' of the resources.

Table 2. Proximate composition (wet/wt) and $\mathrm{pH}$ of mince blend $\mathrm{C}$ and fish sausage ${ }^{1}$

\begin{tabular}{lccccc}
\hline \multicolumn{1}{c}{ Source } & Moisture (\%) & Protein (\%) & Lipid (\%) & Ash (\%) & pH \\
\hline Mince blend & & & & & \\
UM & $76.12 \pm 2.03$ & $17.50 \pm 0.88$ & $5.21 \pm 0.48$ & $1.48 \pm 0.05$ & $6.3 \pm 0.10$ \\
WM & $82.22 \pm 1.67$ & $17.17 \pm 2.21$ & $0.91 \pm 0.04$ & $0.37 \pm 0.01$ & $6.7 \pm 0.08$ \\
Cooked & & & & & \\
Sausage $_{\text {UM }}$ & & & & & \\
WM & $77.34 \pm 2.22$ & $16.14 \pm 1.56$ & $2.67 \pm 0.03$ & $3.62 \pm 0.05$ & $6.2 \pm 0.11$ \\
\hline
\end{tabular}

${ }^{1}$ Results are the mean \pm S.E of 3 individual measurements. $\mathrm{UM}=$ unwashed mince; $\mathrm{WM}=$ washed mince; ${ }^{2}$ Mince paste added with ingredients was cooked at $50^{\circ} \mathrm{C}$ for $60 \mathrm{~min}$. and at $100^{\circ} \mathrm{C}$ for 30 $\min$.

Table 3. Benefit of total utilization of fish in terms of mince recovery $(\mathrm{g})$

\begin{tabular}{l|c|c|c|c|c|c|c|c}
\hline \multirow{2}{*}{ Fish } & \multicolumn{9}{c}{ Unwashed mince } & \multicolumn{2}{c}{ Washed mince } \\
\cline { 2 - 9 } & Whole & Dressed $^{1}$ & Head & Frame & Mince & \% solid & mince & $\%$ solid \\
\hline Sea catfish & 2300 & 1786 & 660 & 208 & 918 & & 1135 & 10.5 \\
& & $(82 \%)$ & $(28 \%)$ & $(9 \%)$ & $(40 \%)$ & 18.1 & $(49 \%)$ & \\
Bombay & 230 & 182 & 45 & 27 & 110 & 15.2 & 142 & 8.2 \\
Duck & & $(79 \%)$ & $(20 \%)$ & $(12 \%)$ & $(48 \%)$ & & $(62 \%)$ & \\
Skipjack & 2250 & 1800 & 484 & 211 & 1125 & 19.6 & 1260 & 12.2 \\
Tuna & & $(80 \%)$ & $(21.5 \%)$ & $(9.4 \%)$ & $(50 \%)$ & & $(56 \%)$ & \\
\hline
\end{tabular}

${ }^{1}$ Dressed, eviscerated and skinned; Figures in parenthesis show percent yield 
Individual gel forming ability of the minces in terms of gel strength varied in great extent due to their compositional differences. Individual gelling performances of six different composition of mince blend were presented in the Table 4 . It was observed that blend number $\mathrm{C}$ showed maximum gelling performance, where higher proportion of minces came from red jewfish, sea catfish and horse mackerel that gave the best gel. We found that, individually red jewfish and sea catfish had higher gelling ability. The results reflected well with the better individual gelling performance of jewfish mince as also confirmed by other authors (Holmes et al., 1992).

Table 4. Ratio of mince blends and their gelling performance

\begin{tabular}{l|c|c|c|c|c|c}
\hline \multirow{2}{*}{ Fish } & \multicolumn{7}{c}{ \% share of individual mince in the mince blend } \\
\cline { 2 - 7 } & A & B & C & D & E & F \\
\hline Red jewfish & 20 & 20 & 30 & 15 & 15 & 20 \\
Sea catfish & 20 & 30 & 20 & 15 & 20 & 15 \\
Horse mackerel & 20 & 20 & 20 & 20 & 15 & 15 \\
Jeweled shad & 20 & 15 & 15 & 20 & 20 & 30 \\
Skipjack tuna & 20 & 15 & 15 & 30 & 30 & 20 \\
Gel strength $(\mathrm{g} \times \mathrm{cm})$ & $548 \pm 78$ & $586 \pm 72$ & $655 \pm 65$ & $445 \pm 124$ & $468 \pm 65$ & $450 \pm 40$ \\
\hline
\end{tabular}

${ }^{* 1}$ Mince blends were ground with $2.5 \% \mathrm{NaCl}$, stuffed into casing, cooked at $90{ }^{\circ} \mathrm{C}$ for $30 \mathrm{~min}$ and the gel thus formed were subjected to puncture test

Gel strength in terms of breaking strength $\times$ breaking deformation of the mince blend number $\mathrm{C}$ was compared with the gelling performance of the individual minces. The results have been presented in the Fig. 2, 3 and 4. This experiment was conducted to find out the optimum heating schedule for attaining maximum textural quality of the product. The unwashed and washed mince blend $C$ were stuffed into sausage casing and incubated at different temperature regimes from $35^{\circ}$ to $55^{\circ} \mathrm{C}$ and then cooked at $90^{\circ}, 95^{\circ}$ and $100^{\circ} \mathrm{C}$. Most of the individual unwashed (Fig. 2) and washed (Figs. 4 and 5) minces showed optimum gelling ability at $50^{\circ} \mathrm{C}$ for 1 hour incubation and further cooking the incubated gel at $100^{\circ} \mathrm{C}$ optimally increased the gelling ability, as generally seen in the two- step heated gel (Niwa, 1992). The gel strength of the mince blends were significantly low in all heating regimes compared to the individual fish minces. But the gel strength of the blend $C$ was still strong enough to be formulated into heat processed products if compared to the mince of other meat sources like poultry or spent hen (Nowsad et al. 2000b). Like wise the individual minces, unwashed and washed mince blends also showed optimum gelling ability at $50^{\circ} \mathrm{C}$ for $1 \mathrm{hr}$ incubation and $100^{\circ} \mathrm{C}$ or $90^{\circ} \mathrm{C}$ cooking for 30 minutes, respectively. Therefore, during subsequent preparation of sausages from the unwashed mince blend No. C, this optimized heating schedule $\left(50^{\circ} \mathrm{C}\right.$ for $1 \mathrm{hr} . ; 100^{\circ} \mathrm{C}$ for 30 minutes) was applied.

The quality attribute of sausage prepared under different cooking processes like, twostep heating (incubation at $45^{\circ}, 50^{\circ}$ and $55^{\circ} \mathrm{C}$ for $60 \mathrm{~min}$. and then cooking at $100^{\circ} \mathrm{C}$ for 30 
min); boiling (20, 30 and $60 \mathrm{~min})$; broiling/steaming (20, 30 and $40 \mathrm{~min})$; and autoclave cooking $\left(110-125^{\circ} \mathrm{C}\right.$ at $15 \mathrm{Ibs}_{\text {.inch }}^{-2}$ for 10 to $\left.20 \mathrm{~min}\right)$ were shown Table 5. In case of twostep heating all the incubation temperatures showed more or less similar gel quality in both instrumental and sensory analysis. Cooking the product at $100^{\circ} \mathrm{C}$ for 30 minutes after incubation at $50^{\circ} \mathrm{C}$ for 1 hour although gave higher breaking force (BF) but the folding test (FT) and the sensory chewniness/rubberiness (C/R) values were identical in all cases. Cooking loss (CL) was decreased with the increment of incubation temperature. $\mathrm{CL}$ values were substantially decreased in direct boiling. Sausages prepared with steaming had lower BF, CR and FT values with corresponding higher values of CL. A good textured sausage was prepared by cooking the stuffed casing in the autoclave at higher temperatures. Among the four higher temperatures tested, autoclaved cooking at $115^{\circ} \mathrm{C}$ for $15 \mathrm{~min}$. obtained best textured sausage with significantly increased $\mathrm{BF}, \mathrm{FT}$ and $C / R$ values and decreased $C L$ values. Sausages prepared at $115^{\circ}$ and $120^{\circ} \mathrm{C}$, however, showed almost identical textural quality. Various authors (Victor and Chandasekhar, 1986) observed the substantial increment of textural quality in pressure induced high temperature cooked gels.

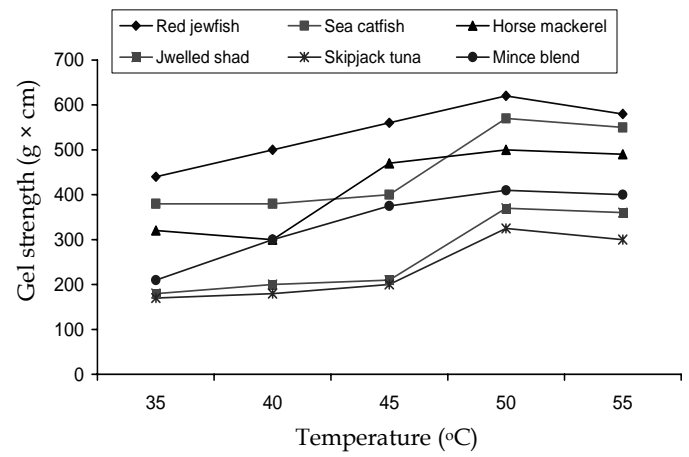

Fig. 2. Gel strength of different unwashed minces and unwashed minces blend during incubation for 1 hr.

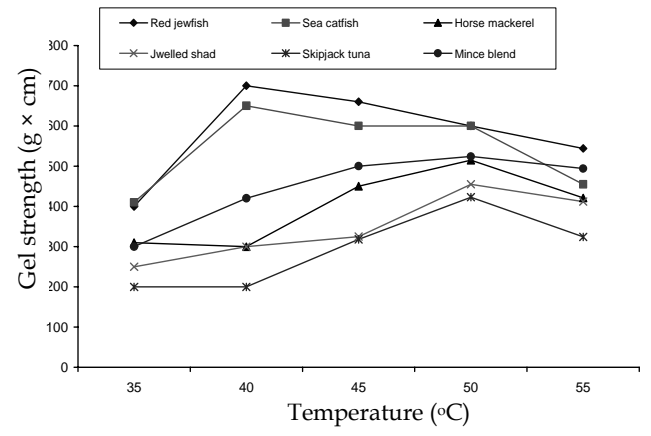

Fig. 4. Gel strength of different washed minces and

washed mince blend during incubation for $1 \mathrm{hr}$.

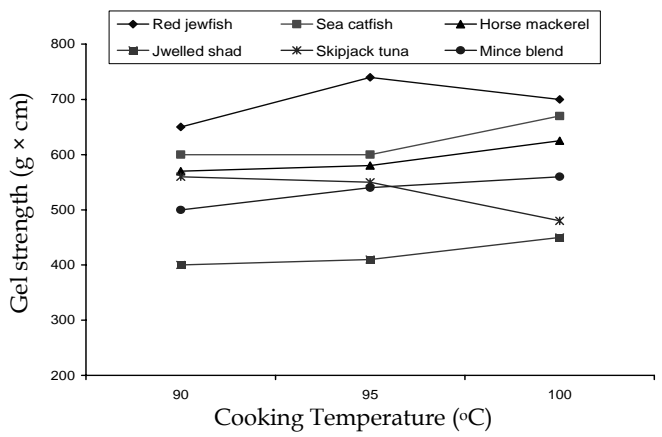

Fig. 3. Gel strength of different unwashed minces and unwashed minces blend at cooking for $30 \mathrm{~min}$. after incubation

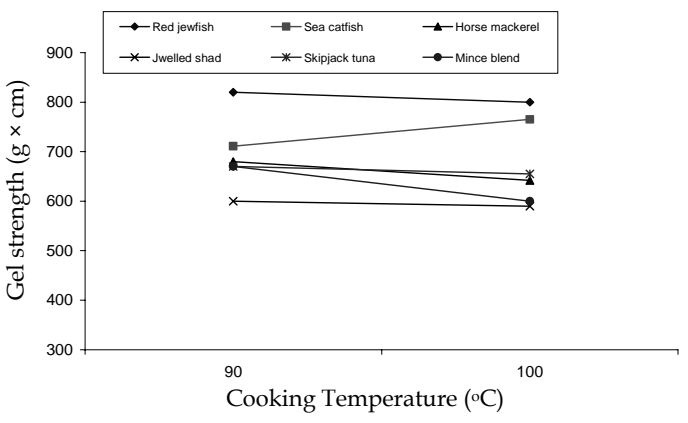

Fig. 5. Gel strength (BF in g) of different washed minces and washed mince blend at two step heating 
Table 5. Quality attributes of sausage prepared by different cooking regime

\begin{tabular}{l|c|c|c|c|c|c|c|c|c|c|c|c|c}
\hline \multirow{2}{*}{ Attributes } & \multicolumn{3}{|c|}{ 2-step heating*1 $\left({ }^{\circ} \mathrm{C}\right)$} & \multicolumn{3}{|c|}{ Boiling $(\mathrm{min})$} & \multicolumn{3}{c|}{ Broiling $(\mathrm{min})$} & \multicolumn{5}{c}{ Autoclaving $\left({ }^{\circ} \mathrm{C}\right)$} \\
\cline { 2 - 15 } & 45 & 50 & 55 & 20 & 30 & 60 & 20 & 30 & 40 & 110 & 115 & 120 & 125 \\
\hline BF (g) & 510 & 550 & 490 & 455 & 524 & 500 & 322 & 428 & 400 & 620 & 645 & 684 & 620 \\
FT (Scale) & $\mathrm{A}+$ & $\mathrm{A}+$ & $\mathrm{A}+$ & $\mathrm{A}$ & $\mathrm{A}+$ & $\mathrm{A}+$ & $\mathrm{B}++$ & $\mathrm{A}$ & $\mathrm{A}$ & $\mathrm{A}$ & $\mathrm{A}++$ & $\mathrm{A}++$ & $\mathrm{A}++$ \\
$\mathrm{CL}(\%)$ & 16.2 & 15.8 & 15.5 & 13.5 & 13.3 & 13.9 & 16.1 & 15.8 & 16.0 & 12.0 & 11.9 & 11.3 & 11.5 \\
$\mathrm{C} / \mathrm{R}$ & 7.1 & 7.2 & 6.9 & 6.2 & 7.5 & 7.0 & 5.8 & 7.1 & 6.2 & 7.9 & 7.8 & 8.2 & 8.5 \\
\hline
\end{tabular}

${ }^{{ }_{1} 1}$ After incubating stuffed sausage were cooked at $100^{\circ} \mathrm{C}$ for $30 \mathrm{~min}$

Low textural quality of unwashed mince blend No. C in terms of GFA, folding test (FT) and cook loss (CL) was improved by incorporating different gel enhancing ingredients, like soybean protein isolate, potato starch, local starch based vegetables and grains and spices. The present study showed that the use of unwashed mince saved a $40-50 \%$ of the total solid of the whole mince in the form of sarcoplasmic protein and minerals along with valuable lipids. Therefore, unwashed mince blends of low-cost marine fish could be used in the value-added product formulation. Further research is, however, needed to assess the keeping quality in terms of chemical and microbilogical properties of new sausage.

\section{ACKNOWLEDGEMENT}

The research was supported by the international Foundation for Science and COSMOTECH through a grant No. E/2551-2 which is gratefully acknowledged.

\section{REFERENCES}

Alam, A. K. M, N., Ali, M. F and Azad, M. A. K. 2004. Development of value- added products from by-catch and underutilized fisheries organisms and pilot market testing of product acceptability among rural communities. Bang. J. Fish., (Special Issue, 2004), 27: 31-32.

Alam, A. K. M. N. 2006. Development of improved methods for the preparation of fish sausage and fish ball from mixed mince of by-catch species in Bangladesh. (Extended summery). BAU Res. Prog. $17: 84$.

AOAC. 1990. “Official Methods of Analysis." 15th ed. Association of Official Analytical Chemists, Washington, DC.

Babbitt, J., Reppond, K., Andrew, H., Thoms, Z. and Swafford, T. C. 1985. Effect of washing on the composition and functional stability of minced pollack flesh. In, Proc. of the International Symposium on Enginered Seafood Including Surimi. Martine, R. E. (edn.) National Fisheries Institute, Washington, DC.

Bertak, J. A. and Karahadian, C. 1995. Surimi-based imitation crab characteristics affected by heating method and end point temperature. J. Food Sci., 60 : 292-296.

Holmes, K. L., Satoshi, F. N. and Grant, A. M. 1992. The Alaska pollack resource and other species used for surimi. In, Surimi Technology. Lanier, T. C. and Lee, C. M. (ed.) Marcel Dekker Inc. New York. 528 p.

Lee, C. M. 1984. Surimi process technology. Food Technol., 38(11) : 69-80. 
Niwa, E. 1992. Chemistry of surimi gelation. In, Surimi Technology. Lanier, T. C. and Lee, C. M. (eds.). Marcel Dekker Inc. New York. 528 p.

Nowsad, A. A., Hoque, M. E. and Sarker, F. C. 2000a. First report of the formulation and development of fish sausage from underutilized marine fish in Bangladesh: fish sausage from sea catfish and Bombay duck. Bang. J. Fish., 23(2) : 107-112.

Nowsad, A. A., Kanoh, S. and Niwa, E. 2000b. Thermal gelation characteristics of breast and thigh muscles of spent hen and broiler and their surimi. Meat sci., 54 : (2000) 169-75.

Nowsad, A. A. and Hoque, M. S. 2007. New fish sausage prepared from unwashed mince blend of low-cost marine fish. Asia Fish. Sci. MS.

Reppond, K. D., Babbitt, J. K., Berntesen, S. and Tsuruta, M. 1995. Gel properties of surimi from Pacific herring. J. Food Sci., 60(4) : 707-710.

Roussel, H. and Cheftel, J. C. 1988. Characteristics of surimi and kamaboko from sardine. Int. J. Food Sci. Technol., 23 : 607-623.

Shil, R. N. and Debnath, S. C. 1992. An Introduction to the Theory of Statistics. 2nd edn., Publisher Minati Shil and Anita Debnath, Mymensingh, 240-320 p.

Shimizu, Y., Machida, R. and Takenami, S. 1981. Spcecies variation in the gel forming characteristics of fish meat paste. Bull. Japan Soc. Sci., 47(1) : 95-104.

Szczesniak, A. S., Brandt, M. A. and Frriedman, H. H. 1963. Development of standard rating scales for mechanical parameters of texture and correlation between the objective and sensory methods of texture evaluation. J. Food Sci., $28: 397-403$.

Victor, R. C. M. and Chandrasekhar, T. C. 1986. High temperature processing of fish sausage an improved technology. J. Fish Technol., 23(2) : 146-148.

Webb, N. B., David, L. and Webb, F. 1985. Functionality of surimi in processed meat systems. In, Proc. of the International Symposium on Engineered Seafood Including Surimi. Martin, R.E. (Ed.). National Fisheries Institute, Washington, DC. 